\title{
Assessment of the permissible exposure level to manganese in workers exposed to manganese dioxide dust
}

\author{
H A Roels, P Ghyselen, J P Buchet, E Ceulemans, R R Lauwerys
}

\begin{abstract}
The prevalence of neuropsychological and respiratory symptoms, lung ventilatory parameters, neurofunctional performances (visual reaction time, eye-hand coordination, hand steadiness, audioverbal short term memory), and several biological parameters (calcium, iron, luteinising hormone (LH), follicle stimulating hormone (FSH), and prolactin concentrations in serum, blood counts, manganese (Mn) concentration in blood and in urine) were examined in a group of workers $(n=92)$ exposed to $\mathrm{MnO}_{2}$ dust in a dry alkaline battery factory and a matched control group $(n=101)$. In the battery plant, the current exposure of the workers to airborne Mn was measured with personal samplers and amounted on average (geometric mean) to 215 and $948 \mu \mathrm{g} \mathrm{Mn} / \mathrm{m}^{3}$ for respirable and total dust respectively. For each worker, the lifetime integrated exposure to respirable and total airborne Mn dust was also assessed. The geometric means of the $M n$ concentrations in blood (MnB) and in urine (MnU) were significantly higher in the Mn exposed group than in the control group (MnB 0.81 $v 0.68 \mu \mathrm{g}$ ) $100 \mathrm{ml}$; MnU 0.84 $v 0.09 \mu \mathrm{g} / \mathrm{g}$ creatinine). On an individual basis, $M n U$ and $M n B$ were not related to various external exposure parameters (duration of exposure, current exposure, or lifetime integrated exposure to airborne $\mathrm{Mn}$ ). On a group basis, a statistically significant association was found between MnU and current $M n$ concentrations in air. No appreciable difference between the exposed and the control workers was found with regard to the other biological measurements (calcium,
\end{abstract}

Industrial Toxicology and Occupational Medicine Unit, School of Medicine, Catholic University of Louvain, B-1200 Brussels, Belgium

H A Roels, P Ghyselen, J P Buchet, R R Lauwerys

Medi-Leuven, B-3010 Kessel-Lo, Belgium

E Ceulemans
LH, FSH, and prolactin in serum). Although the erythropoietic parameters and serum iron concentration were in the normal range for both groups, there was a statistically significant trend towards lower values in the Mn exposed workers. The prevalences of reported neuropsychological and respiratory symptoms, the lung function parameters, and the audioverbal short term memory scores did not differ between the control and exposed groups. The Mn workers, however, performed the other neurofunctional tests (visual reaction time, eye-hand coordination, hand steadiness) less satisfactorily than the control workers. For these tests, the prevalences of abnormal results were related to the lifetime integrated exposure to total and respirable Mn dust. On the basis of logistic regression analysis it may be inferred that an increased risk of peripheral tremor exists when the lifetime integrated exposure to Mn dust exceeds 3575 or $730 \mu \mathrm{g}$ $\mathrm{Mn} / \mathrm{m}^{3} \times$ year for total and respirable dust respectively. The results clearly support a previous proposal by the authors to decrease the current time weighted average exposure to Mn dust.

The two main target organs affected by chronic exposure to manganese (Mn) dust are the lungs (increased incidence of pneumonia, bronchitis, and chronic non-specific lung disease) and the central nervous system (neurobehavioural symptoms and neurological signs characteristic of an extrapyramidal syndrome that has several similarities to Parkinson's disease). ${ }^{1}$

A recent cross sectional study ${ }^{2}$ carried out by our laboratory among 141 male workers exposed to inorganic Mn dust in a $\mathrm{Mn}$ oxide and salt producing plant has suggested that long term exposure to airborne $\mathrm{Mn}$ concentrations below the current time weighted average exposure (TWA) $\left(5 \mathrm{mg} / \mathrm{m}^{3}\right.$ for total dust) may still lead to impairment of lung ventilatory function, alteration of neurofunctional performances (slowed visual reaction time, impaired 
audioverbal short term memory, decreased hand steadiness, and impaired eye-hand coordination), and changes in $\mathrm{Ca}$ homeostasis. Some results also indicate that $\mathrm{Mn}$ might interfere with male fertility. ${ }^{3}$

To assess the validity of the conclusion that the current TWA for Mn does not prevent adverse effects in a significant proportion of the exposed subjects, another cross sectional epidemiological study was undertaken among workers exposed to $\mathrm{MnO}_{2}$ dust in a dry alkaline battery plant and their results were compared with those of a matched control group. The design of the present study was again aimed at the detection of preclinical effects of $\mathrm{Mn}$ on lung ventilatory parameters, neurofunctional performances, and some serum parameters reflecting the activity of the hypothalamo pituitary testicular axis (follicle stimulating hormone (FSH), luteinising hormone (LH), prolactin). An effort was also made to estimate quantitatively the lifetime integrated occupational exposure to respirable and total airborne $M n$ dust ( $\mu \mathrm{g} \mathrm{Mn} / \mathrm{m}^{3} \times$ year) of each $\mathrm{Mn}$ exposed worker.

\section{Subjects and methods}

STUDY POPULATION AND STUDY DESIGN

The $\mathrm{Mn}$ exposed group was occupied in a large dry alkaline battery plant with a total workforce of about 1100 employees of whom the 102 workers currently exposed to $\mathrm{MnO}_{2}$ dust volunteered to participate. A group of 104 age matched control workers not exposed to neurotoxic chemicals or lung irritants was recruited in a polymer processing factory. Because both plants are located in the same area, have the same occupational physician, and apply similar hiring criteria, an efficient matching between the $\mathbf{M n}$ and control groups was achieved with regard to socioeconomic state (salary, education), general environment (place of residence), and workshift and workload characteristics. About $25 \%$ of the subjects in each group were employed on a permanent night shift $(10.00 \mathrm{pm}-6.00 \mathrm{am})$ whereas the others alternated weekly from the $6.00 \mathrm{am}-2.00 \mathrm{pm}$ shift to the $2.00 \mathrm{pm}-10.00 \mathrm{pm}$ shift. Potential confounding factors related to hobby activities or previous employment, personal habits (smoking, coffee, and alcohol consumption), and medical history were controlled by questionnaire and interview. At the time of the survey, all the participants were in good health. To be included in the final database, participants should never have been occupationally exposed to mercury, lead, cadmium, solvents, or hazards interfering with lung function. At the time of the examination the concentrations of lead $(\mathrm{PbB})$ and zinc protoporphyrin (ZPP) in blood and of cadmium $(\mathrm{CdU})$ and mercury ( $\mathrm{HgU})$ in urine had to be in the normal range-namely, $\mathrm{PbB}<35 \mu \mathrm{g} / 100 \mathrm{ml}$, $\mathrm{ZPP}<2.5 \mu \mathrm{g} / \mathrm{g} \mathrm{Hb}, \mathrm{CdU}<2 \mu \mathrm{g} / \mathrm{g}$ creatinine, and $\mathrm{HgU}<10 \mu \mathrm{g} / \mathrm{g}$ creatinine. Furthermore, par- ticipants should not suffer or have suffered from lung diseases and their medical history should not show neurological or neuropsychiatric affections or current medical treatment that might influence the results of the neurofunctional tests. In total 13 subjects did not meet the selection criteria (three control and four exposed subjects for medical reasons; six exposed subjects for previous or current exposure to mercury or lead), so that eventually the data analysis was performed on 101 control and $92 \mathrm{Mn}$ exposed subjects.

The outline of the study protocol was similar to that of our previous study. ${ }^{2}$ The clinical examination was carried out in the medical departments of the plants. At a rate of about eight subjects each shift, the morning and afternoon shift workers were examined on a Tuesday and a Wednesday between 8.30 am and $6.00 \mathrm{pm}$, and the night shift workers on a Thursday between $10.00 \mathrm{pm}$ and $2.30 \mathrm{am}$. The workers first took a shower, put on their civil clothes before starting the examination, and were asked to refrain from smoking for at least one hour before showering. The survey was conducted by two trained persons who took care of the same part of the examinations throughout the whole study period and who respected the following sequence: physical examination, blood and urine sampling for biological analyses, control of questionnaire, and performance of spirometric and neurofunctional tests.

\section{AIR SAMPLING}

The exposure of each worker to airborne $\mathrm{Mn}$ was characterised by personal sampling. The Mn concentration in "total" and "respirable" dust was determined in the breathing zone of the workers with the use of a Casella cyclone elutriator/filter head (type 13043/1) equipped with an integral pulsation smoother connected to a battery operated Casella pump (type 13051/2) (Casella Ltd, London). A cellulose ester filter (Millipore filter type AAWP03700) was placed in the filter cassette to collect the "respirable" fraction (Johannesburg's curve), whereas the grit pot was equipped with a plastic cup to collect the "non-respirable" fraction (total $=$ respirable fraction + non-respirable fraction). Air was sampled at a mean flow rate of 1.85 (SD $0.44) \mathrm{l} / \mathrm{min}$. The air sampling exceeded 4.5 hours in $80 \%$ of the measurements and was carried out during a period representative of each worker's usual activities. The Mn contents of the respirable and non-respirable fractions were determined by flame atomic absorption spectrometry (Perkin-Elmer, Model 305) as described before. ${ }^{4}$

\section{CLINICAL EXAMINATION}

The self administered questionnaire (personal details, occupational and medical history, neurovegetative complaints, respiratory symptoms) 
and the procedure for its completion were similar to those used before. ${ }^{2}$ Special emphasis was placed on listing the details of previous job assignment(s) in the dry alkaline battery plant for each $\mathrm{Mn}$ exposed worker to calculate the estimated lifetime integrated exposure to respirable and total airborne Mn dust. The questions to detect respiratory symptoms were taken from the revised 1987 questionnaire of the European Community of Coal and Steel for the epidemiology of chronic bronchitis.

Lung function was assessed by recording maximal expiratory volume curves with a Vitalograph type $S$ spirometer coupled to a Vitalograph electronic function analyser 21-300A (Buckingham, UK). Spirograms were performed on each subject sitting in an upright position: two vital capacity manoeuvres were followed by forced vital capacity (FVC) tests until three acceptable FVC tracings were obtained. The spirometer was checked twice a day by means of a calibrated syringe with a volume displacement of 31 . All spirometric measurements were corrected to body temperature, pressure, and saturation conditions $\left(37^{\circ} \mathrm{C}, 760 \mathrm{mmHg}\right)$. The $\%$ predicted values were calculated for FVC, forced expiratory volume in one second $\left(\mathrm{FEV}_{1}\right), \mathrm{FEV}_{1} / \mathrm{FVC}$, and forced expiratory flow at $25-75 \%$ of $\mathrm{FVC}\left(\mathrm{FEF}_{25-75}\right)$ using the prediction equations of Crapo et al. ${ }^{5}$

Neurofunctional examination comprised an audioverbal short term memory test, a simple visual reaction time measurement over $4 \times 2$ minutes using a chronoscope (EAP, Issy-les-Moulineaux, France), a hand steadiness test $(3 \times 7$ holes, 15 seconds per hole, hole diameter 8 to $3.5 \mathrm{~mm}$ ), and a eye-hand coordination test $(2 \times 1 \mathrm{~min})$ using the hole tremormeter and orthokinesimeter of the apparatus of Bize (EAP, Issy-les-Moulineaux, France) (the last three tests were performed with the dominant hand only). This neurofunctional assessment was carried out according to the same methodology (instruments, standardised modes of application, and calculation of results) as that described in our previous investigations. ${ }^{267}$ For the eye-hand coordination test, however, the subject was requested to perform the test at a speed imposed by a metronome $(1 \mathrm{hit} / \mathrm{s})$.

\section{BIOLOGICAL ANALYSES}

A sample of venous blood $(20 \mathrm{ml})$ and a spot urine sample $(50 \mathrm{ml})$ were collected on the day of the clinical examination. Syringes, tubes, and urine containers were previously checked for lack of heavy metal contamination. Blood samples were divided as follows: $5 \mathrm{ml}$ in Sarstedt Monovette EDTA-K tubes for haematological analyses, $5 \mathrm{ml}$ in polypropylene tubes (containing $50 \mu \mathrm{l}$ EDTA- $\mathrm{Na}_{2}(10 \%)$ for lead, $\mathrm{Mn}$, and ZPP analysis, and $10 \mathrm{ml}$ in plain tubes for the serum measurements of calcium, iron, and the pituitary hormones FSH, LH, and prolactin. Blood and urine samples were kept at $4^{\circ} \mathrm{C}$ and analysed as soon as possible; serum samples were stored at $-20^{\circ} \mathrm{C}$ after serum iron concentration was determined.

The concentrations of $\mathrm{Mn}$ and lead in whole blood were determined by electrothermal atomic absorption spectrometry using STPF techniques coupled with a Zeeman effect background correction system (Perkin Elmer Zeeman 3030). An aliquot of $0.1 \mathrm{ml}$ blood was diluted with $0.4 \mathrm{ml}$ Triton X-100 (0.2\%) and $0.5 \mathrm{ml} \mathrm{HNO} \mathrm{HN}_{3}(0.05 \mathrm{M})$; the method of external standard line in a whole blood matrix was used. The urinary concentrations of $\mathrm{Mn}$ and cadmium were also determined by flameless atomic absorption techniques $^{89}$ using an HGA-400 atomiser unit in conjunction with a Perkin-Elmer 5000 spectrometer equipped with a deuterium background corrector. Total mercury concentration in urine was measured with an automated "cold vapour" atomic absorption technique. ${ }^{10}$ Serum iron concentration was assayed spectrophotometrically with sulphonated bathophenanthroline (Merckotest kit 3307). After three months of storage at $-20^{\circ} \mathrm{C}$, the serum samples of control and exposed subjects were analysed simultaneously for calcium by flame atomic absorption ${ }^{2}$ (Perkin-Elmer 305) and for the three pituitary hormones with the radioimmunoassay kits purchased from Amersham International (Amersham, UK) (Amerlex-M FSH, code IM 3071; Amerlex-M LH, code IM 3081; Prolactin, code IM 1061). The radioactivity $\left({ }^{125} \mathrm{I}\right)$ in the final precipitate was counted in a $\gamma$-counter Berthold BF5300 (Wildbad, Germany). The simultaneous measurements of certified control sera (QAS 105 and 109) showed results within the tolerance limits specified by Amersham International. Measurement of ZPP concentration was carried out with a haematofluorimeter (Aviv Associates, Lakewood, NJ), and a Technicon $\mathrm{H6000}$ was used for routine haematological analyses (red blood cell count, white blood cell count, haemoglobin, haematocrit, mean corpuscular volume, mean corpuscular haemoglobin, mean corpuscular haemoglobin concentration, platelets, leucocyte formula). Urinary creatinine concentration was determined according to Jaffe's picrate method. ${ }^{11}$

\section{STATISTICAL ANALYSIS}

Statistical analyses were by SAS procedures. ${ }^{12}$ Variables with a skewed distribution were logarithmically transformed to approximate the normal distribution. The Pearson correlation coefficient $(r)$ and regression equation or Spearman rank correlation coefficient ( $r$ ) were calculated to assess the association between variables. The association between lifetime integrated exposure to airborne respirable or total Mn dust and the probability of abnormal neurofunctional outcomes were analysed using the logistic regression model, $\ln \frac{\mathrm{p}}{1-\mathrm{p}}=\beta_{0}+\beta_{1} \mathrm{x}_{1}$, where $\mathrm{x}_{1}$ 
was either $\log$ LIRD or $\log$ LITD. $\beta_{1}$ was expressed in terms of odds ratio (OR) for subjects with characteristics $\mathrm{x}_{1}$ and $\mathrm{x}_{1}{ }^{\star}$, and its $95 \%$ confidence interval $(95 \% \mathrm{CI})$ was also calculated. ${ }^{13} \mathrm{~A}$ p value $\leqslant 0.05$ was considered as the criterion of statistical significance.

\section{Results \\ POPULATION CHARACTERISTICS}

Table 1 summarises some characteristics of the control and $\mathrm{Mn}$ exposed workers. Both groups were young (mean age about 30 years); the $\mathrm{Mn}$ group had been exposed to $\mathrm{MnO}_{2}$ for 5.3 years on average (range $0 \cdot 2-17 \cdot 7)$. Both populations were well matched for age, height, weight, work schedule, coffee and alcohol consumption, and smoking (no statistically significant differences between control and $\mathrm{Mn}$ groups). A small difference in educational level existed between the two groups ( $\chi^{2}$ test, $\left.\mathrm{p}=0.046\right)$ due to a greater proportion of workers with a technical degree in the control plant.

\section{EXPOSURE PARAMETERS}

\section{External exposure to manganese}

Figure 1 gives the results of the current airborne $\mathrm{Mn}$ determinations by personal sampling (respirable dust, range $21-1317 \mu \mathrm{g} \mathrm{Mn} / \mathrm{m}^{3}$; total dust, range $46-$ $10840 \mu \mathrm{g} \mathrm{Mn} / \mathrm{m}^{3}$ ). These data are representative of the usual exposure of the workers because the work processes have not been modified during the last 15 years. Most workers $(90 \%)$ were exposed to $\mathrm{Mn}$ concentrations below the currently recommended American Conference of Governmental Industrial Hygienists' TWA for total dust $\left(5000 \mu \mathrm{g} / \mathrm{m}^{3}\right)$. The 95 percentile values amounted to 907 and $7115 \mu \mathrm{g} / \mathrm{m}^{3}$ for respirable and total dust respectively. A strong linear correlation $(r=0.90, p<0.001)$ was found between the Mn concentrations (log values) of total (CTD) and respirable dust (CRD) : log CRD $\left(\mu \mathrm{g} \mathrm{Mn} / \mathrm{m}^{3}\right)=0.3433+0.6761 \log$ CTD $(\mu \mathrm{g} \mathrm{Mn} /$ $\left.\mathrm{m}^{3}\right)$. On average, the $\mathrm{Mn}$ content of the respirable fraction represented $25 \%$ of the Mn content in the total dust. The proportion, however, decreased exponentially as a function of increasing total airborne $\mathrm{Mn}: \log ((\mathrm{CRD} / \mathrm{CTD}) \times 100)=2.3442-$ $0.3239 \log \mathrm{CTD}\left(\mu \mathrm{g} \mathrm{Mn} / \mathrm{m}^{3}\right)(\mathrm{r}=-0.71, \mathrm{p}<$ 0.001 ).

Lifetime integrated exposure to $\mathrm{Mn}$ was estimated for each worker. The current airborne Mn concentration characteristic of each job was multiplied by the years during which each worker had performed this activity. Addition of these results gave an estimated lifetime integrated exposure to respirable (LIRD) and total (LITD) dust expressed in $\mu \mathrm{g} \mathrm{Mn} /$ $\mathrm{m}^{3} \times$ year for each worker. The integrated exposure to respirable dust ranged from 40 to 4433 and total dust from 191 to $27465 \mu \mathrm{g} \mathrm{Mn} / \mathrm{m}^{3} \times$ year, and the respective geometric means amounted to 793 and $3505 \mu \mathrm{g} \mathrm{Mn} / \mathrm{m}^{3} \times$ year.

Table 1 Characteristics of control and Mn exposed groups ${ }^{\star}$

\begin{tabular}{|c|c|c|c|c|c|c|}
\hline & \multicolumn{3}{|c|}{ Control $(n=101)$} & \multicolumn{3}{|c|}{ Exposed $(n=92)$} \\
\hline & Mean & $S D$ & Range & Mean & $S D$ & Range \\
\hline $\begin{array}{l}\text { Age }(y) \\
\text { Years of } \mathrm{Mn} \text { exposure } \\
\text { Height }(\mathrm{cm}) \\
\text { Weight }(\mathrm{kg})\end{array}$ & $\begin{array}{r}29 \cdot 3 \\
\frac{175 \cdot 2}{75 \cdot 5}\end{array}$ & $\begin{array}{r}8 \cdot 0 \\
-5 \cdot 9 \\
10 \cdot 3\end{array}$ & $\begin{array}{l}18 \cdot 5-50 \cdot 7 \\
\frac{160-194}{54 \cdot 3-108 \cdot 5}\end{array}$ & $\begin{array}{r}31 \cdot 3 \\
5 \cdot 3 \\
175 \cdot 6 \\
77 \cdot 7\end{array}$ & $\begin{array}{r}7 \cdot 4 \\
3 \cdot 5 \\
5 \cdot 9 \\
10 \cdot 3\end{array}$ & $\begin{array}{c}22 \cdot 0-49 \cdot 6 \\
0 \cdot 2-17 \cdot 7 \\
164-191 \\
58 \cdot 9-110 \cdot 7\end{array}$ \\
\hline $\begin{array}{l}\text { Work schedule: } \\
\text { Day shift (\% of subjects) } \\
\text { Night shift (\% of subjects) }\end{array}$ & $\begin{array}{l}75 \cdot 2 \\
24 \cdot 8\end{array}$ & & & $\begin{array}{l}73 \cdot 9 \\
26 \cdot 1\end{array}$ & & \\
\hline $\begin{array}{l}\text { Educational level: } \\
\text { Primary and junior high school (\% of subjects) } \\
\text { Senior high school and above (\% of subjects) }\end{array}$ & $\begin{array}{l}60 \cdot 4 \\
39 \cdot 6\end{array}$ & & & $\begin{array}{l}73 \cdot 9 \\
26 \cdot 1\end{array}$ & & \\
\hline $\begin{array}{l}\text { Coffee consumption: } \\
\text { Yes }(\% \text { of subjects }) \\
\text { Cups a day }\end{array}$ & $\begin{array}{r}85 \cdot 1 \\
5 \cdot 9\end{array}$ & $4 \cdot 1$ & $1-20$ & $\begin{array}{r}90 \cdot 2 \\
6 \cdot 0\end{array}$ & $4 \cdot 1$ & $1-20$ \\
\hline $\begin{array}{l}\text { Alcohol consumption: } \\
\text { Yes (\% of subjects) } \\
\text { g a week }\end{array}$ & $\begin{array}{l}79 \cdot 2 \\
128\end{array}$ & 98 & $10-550$ & $\begin{array}{c}73.9 \\
128\end{array}$ & 122 & $10-550$ \\
\hline $\begin{array}{l}\text { Smoking habits: } \\
\text { Current smokers } \\
\text { Yes }(\% \text { of subjects }) \\
\text { Pack-years }\end{array}$ & $\begin{array}{l}55 \cdot 4 \\
9 \cdot 2(6 \cdot 1) \dagger\end{array}$ & $+\quad 7.7$ & $0 \cdot 7-32$ & $\begin{array}{l}47 \cdot 8 \\
10 \cdot 3(6 \cdot 8) \dagger\end{array}$ & $+\quad 8.0$ & $0 \cdot 2-42$ \\
\hline $\begin{array}{l}\text { Ex smokers: } \\
\text { Yes (\% of subjects) } \\
\text { Pack-years }\end{array}$ & $\begin{array}{l}13 \cdot 9 \\
11 \cdot 3(3 \cdot 9) \dagger\end{array}$ & $+16 \cdot 1$ & $0 \cdot 3-48$ & $\begin{array}{l}19 \cdot 6 \\
7 \cdot 8(4 \cdot 3)+\end{array}$ & $+\quad 6.0$ & $0 \cdot 2-18 \cdot 7$ \\
\hline $\begin{array}{l}\text { Never smokers: } \\
\text { Yes (\% of subjects) }\end{array}$ & $30 \cdot 7$ & & & $32 \cdot 6$ & & \\
\hline
\end{tabular}

^Comparison between groups: Student's $t$ test for mean values; $2 \times 2 \chi^{2}$ test for proportion of subjects.

†Geometric mean. 


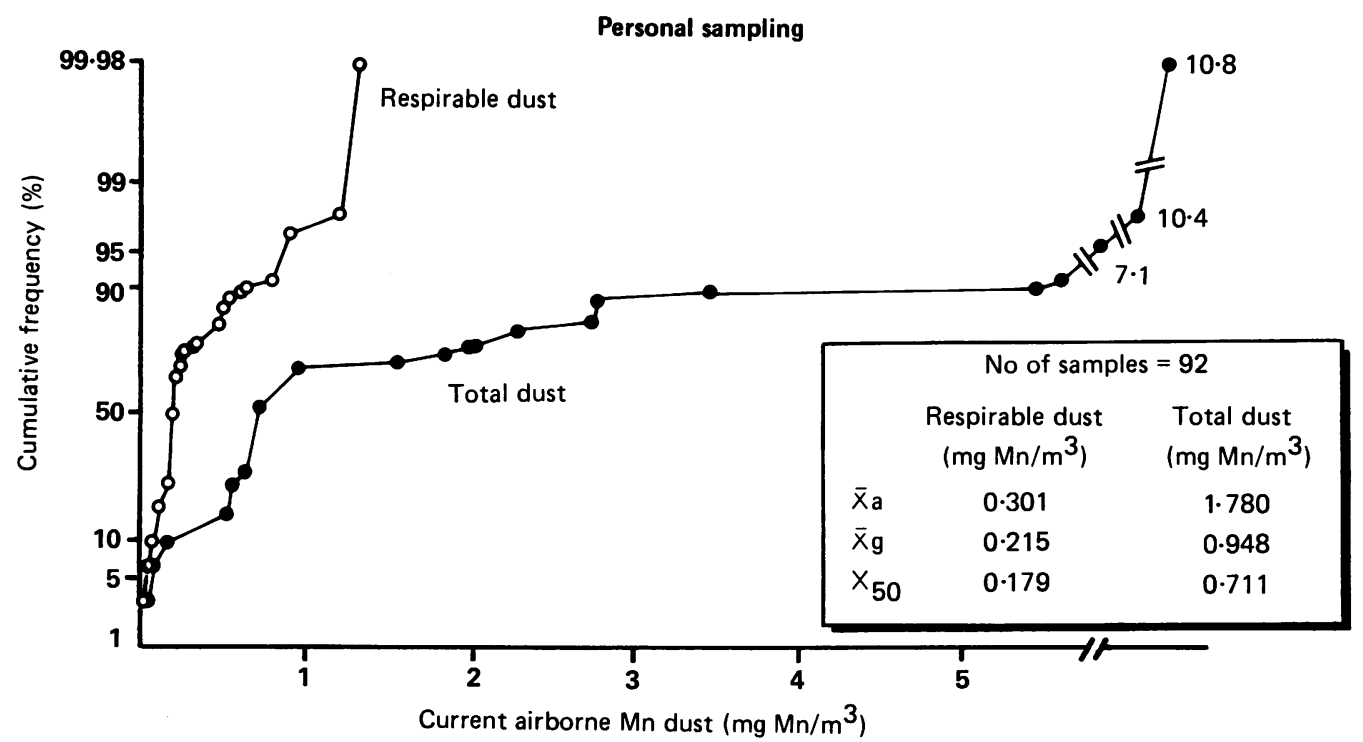

Figure 1 Cumulative frequency distribution of time weighted average concentration of respirable and total airborne Mn dust collected with personal sampler.

\section{Internal exposure to manganese}

The MnB ranged from 0.25 to $1.31 \mu \mathrm{g} / 100 \mathrm{ml}$ in the control group and from 0.21 to $2 \cdot 10 \mu \mathrm{g} / 100 \mathrm{ml}$ in the $\mathrm{Mn}$ exposed group. For $\mathrm{MnU}$, the concentrations ranged from 0.01 to $0.49 \mu \mathrm{g} / \mathrm{g}$ creatinine in the control group and from 0.15 to $7.33 \mu \mathrm{g} / \mathrm{g}$ creatinine in the exposed workers. The geometric means of $\mathrm{MnB}(0.81 \mu \mathrm{g} / 100 \mathrm{ml})$ and $\mathrm{MnU}(0.84 \mu \mathrm{g} / \mathrm{g}$ creatinine) were significantly higher ( $t$ test, $p<0.001)$ in the Mn exposed group than in the control group (MnB $0.68 \mu \mathrm{g} / 100 \mathrm{ml} ; \mathrm{MnU} 0.09 \mu \mathrm{g} / \mathrm{g}$ creatinine). The $\mathrm{MnB}$ exceeded $1 \mu \mathrm{g} / 100 \mathrm{ml}$ in $28 \%$ of the exposed workers compared with $7 \%$ in the control group. For $\mathrm{MnU}, 71 \%$ of the concentrations in the Mn group exceeded the highest value found in the control group.

\section{Relation between parameters of external and internal exposure to manganese}

On an individual basis, no statistically significant correlation was found between $\mathrm{MnB}$ or $\mathrm{MnU}$ and various external exposure parameters (duration of exposure, CRD, CTD, LIRD, LITD). This result is in agreement with our previous observation in workers occupied in a Mn oxide and salt producing plant. ${ }^{4}$

On a group basis, the Mn exposed workers were classified into six subgroups according to current total and current respirable $\mathrm{Mn}$ exposure (six subgroups representative of the main types of activities or workplaces) and in four subgroups according to lifetime integrated exposure. No correlation was found between the average current Mn pollution (log values) at the workplaces and the geometric mean of $\mathrm{MnB}$, whereas a statistically significant rank correlation was found between average current $\mathrm{Mn}$ concentrations in air (log values) and the geometric mean of $\mathrm{MnU}\left(\mathrm{r}_{\mathrm{s}}=0.83\right.$ with both total and respirable dust, $\mathrm{p}$ $<0.05)$. Neither MnB, nor MnU correlated with the lifetime integrated exposure concentrations of respirable or total Mn dust.

\section{EFFECT PARAMETERS}

Respiratory tract

The questionnaire on respiratory symptoms was analysed separately for smokers and non-smokers and for both groups combined. The analysis did not show any statistical difference in the prevalences of reported symptoms between the control and $\mathrm{Mn}$ group (results not shown). The influence of smoking habits and exposure to $\mathrm{Mn}$ on the spirometric parameters (observed and \% predicted values) was examined by a two way analysis of variance; no statistically significant effect of $\mathrm{Mn}$ was found (results not shown). Likewise, the prevalences of spirometric measurements below $80 \%$ of the predicted values were not significantly different between both groups.

\section{Central nervous system}

The analysis of the questionnaire on neurovegetative complaints did not show any significant difference in the prevalences of reported symptoms between the control and $\mathrm{Mn}$ group.

The $\mathrm{Mn}$ workers, however, performed several neurofunctional tests less satisfactorily than the 
Table 2 Mean reaction time $e^{\star}$ (visual) and standard deviation of simple reaction time in control and Mn exposed workers

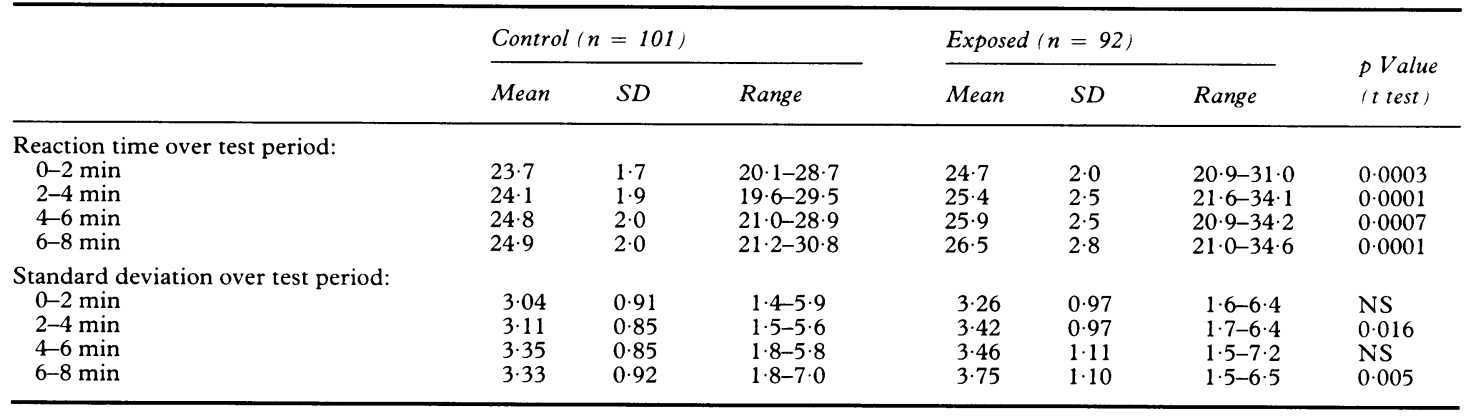

*Expressed in $10^{-2} \mathrm{~s}$.

NS $=$ Not statistically significant.

Table 3 Prevalences of abnormal values of simple visual reaction time in control and $\mathrm{Mn}$ exposed workers

\begin{tabular}{|c|c|c|c|c|}
\hline & $\begin{array}{l}\text { Cut off } \\
\text { value } \\
10^{-2} \mathrm{~s}\end{array}$ & $\begin{array}{l}\text { Control } \\
(n=101) \\
\text { No }(\%)\end{array}$ & $\begin{array}{l}\text { Exposed } \\
(n=92) \\
N o(\%)\end{array}$ & $\begin{array}{l}p \text { Value } \\
\left(\chi^{2} \text { test }\right)\end{array}$ \\
\hline \multicolumn{5}{|c|}{ Mean reaction time over the test period: } \\
\hline $0-2$ minutes & $>26 \cdot 3$ & $5(5 \cdot 0)$ & $17(18 \cdot 5)$ & 0.003 \\
\hline $2-4$ minutes & $>26.9$ & $5(5 \cdot 0)$ & $23(25 \cdot 0)$ & 0.0001 \\
\hline 4-6 minutes & $>28 \cdot 5$ & $4(4 \cdot 0)$ & $10(10.9)$ & NS $(0.065)$ \\
\hline $6-8$ minutes & $>28 \cdot 4$ & $5(5 \cdot 0)$ & $19(20 \cdot 7)$ & 0.001 \\
\hline
\end{tabular}

*95th percentile values of the control group.

NS $=$ Not statistically significant.

control workers. Table 2 compares the mean reaction time and standard deviation for every two minutes of testing between the control and Mn group. The Mn workers had a significantly longer reaction time over the whole testing period than the control group. In both groups the reaction time increased with the duration of the test, but this effect was more pronounced in the exposed group. The standard deviation for each test period was also higher in the exposed group reflecting a higher internal variability in reaction time. The prevalences of abnormal values for the mean reaction time during each test period varied between 11 and $25 \%$ in the Mn group and were 4 or $5 \%$ in the control group (table 3 ).

The results of the five eye-hand coordination parameters (precision, \% precision, imprecision, $\%$ imprecision, uncertainty) indicated that the fine hand-forearm movement was more erratic in the $\mathrm{Mn}$ exposed workers than in the control subjects. The mean score of each parameter was significantly different between both groups (table 4). Figure 2 illustrates the difference in the \% precision score between the control and the Mn group. Likewise, the prevalences of abnormal values for the five eye-hand coordination parameters were significantly higher in the $\mathrm{Mn}$ exposed group ( 15 to $30 \%$ ) than in the control group (5\%) (table 5).

The results of the hole tremormeter test (hand steadiness) showed a systematic tendency towards higher mean tremor scores in the Mn exposed group as compared with the control group (table 6). One of the exposed subjects displayed such a pronounced resting tremor at the time of the test that it was impossible to measure correctly his tremor scores with this technique. The prevalences of abnormal score values were also consistently higher in the $\mathrm{Mn}$ group than in the control group (for example, the prevalences of abnormal results were 4 and $5 \%$ in the control group $v 13$ and $28 \%$ in the Mn group for the $3.5 \mathrm{~mm}$ and $6 \mathrm{~mm}$ holes respectively).

Although the Mn workers performed less well in the audioverbal short term memory test than the control group, the mean scores of correctly recalled or recognised words were not significantly different between both groups (results not shown).

Table 4 Eye-hand coordination scores in control and Mn exposed workers

\begin{tabular}{|c|c|c|c|c|c|c|c|}
\hline & \multicolumn{3}{|c|}{ Control $(n=101)$} & \multicolumn{3}{|c|}{ Exposed $(n=92)$} & \multirow{2}{*}{$\begin{array}{l}\text { p Value }(t \text { test }) \\
(\text { Mann-Whitney U test })^{\star}\end{array}$} \\
\hline & Mean & $S D$ & Range & Mean & $S D$ & Range & \\
\hline $\begin{array}{l}\text { Precision }(\mathrm{N} 1) \\
\text { Imprecision }(\mathrm{N} 3) \\
\text { Uncertainty }(\mathrm{a}) \\
\% \text { Precision }(\mathrm{N} 1 \times 100 / \mathrm{a}) \\
\% \text { Imprecision } \\
(\mathrm{N} 3 \times 100 / \mathrm{a})\end{array}$ & $\begin{array}{c}54 \cdot 6 \\
0 \cdot 14 \\
79 \cdot 7 \\
69 \cdot 2 \\
0 \cdot 13\end{array}$ & $\begin{array}{l}5 \cdot 2 \\
0 \cdot 57 \\
9 \cdot 3 \\
9 \cdot 0 \\
0 \cdot 54\end{array}$ & $\begin{array}{c}34 \cdot 5-68 \cdot 0 \\
0-5 \\
65-114 \\
42 \cdot 1-88 \cdot 1 \\
0 \cdot 0-4 \cdot 4\end{array}$ & $\begin{array}{c}51 \cdot 4 \\
0.70 \\
86 \cdot 8 \\
59 \cdot 9 \\
0.79\end{array}$ & $\begin{array}{c}9 \cdot 8 \\
1.24 \\
16 \cdot 9 \\
10 \cdot 5 \\
1.27\end{array}$ & $\begin{array}{c}32-86 \cdot 5 \\
0-9 \\
67-194 \\
35 \cdot 1-86 \cdot 0 \\
0 \cdot 0-8 \cdot 8\end{array}$ & $\begin{array}{l}0.006(0.0022)^{\star} \\
0.0001(0.0001) \\
0.0005(0.0005) \\
0.0001(0.0001) \\
0.0001(0.0001)\end{array}$ \\
\hline
\end{tabular}




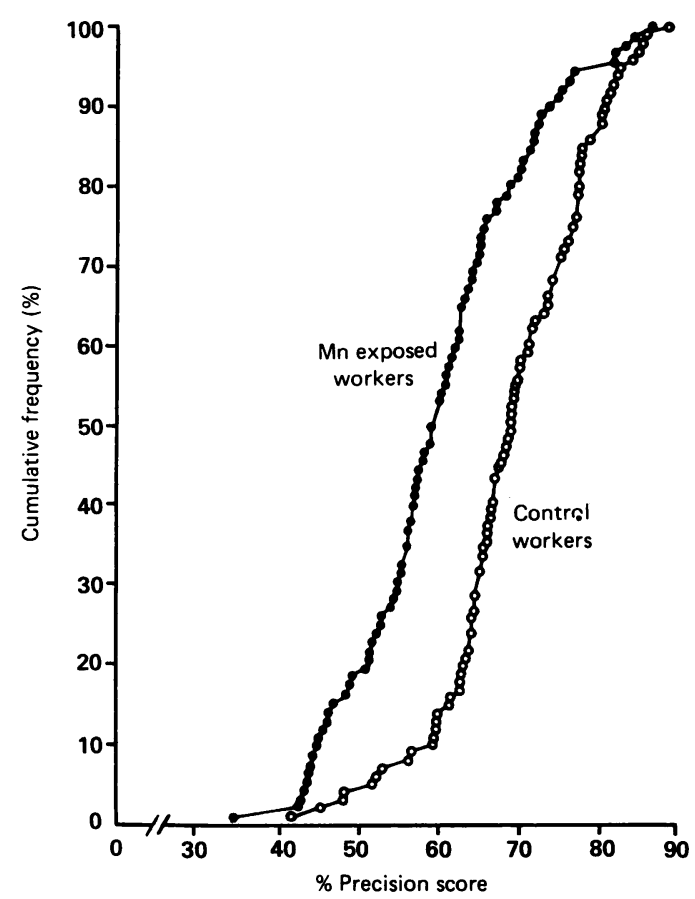

Figure 2 Eye-hand coordination test. Cumulative frequency distribution of $\%$ precision score in control and $M n$ exposed workers $\left(2 \times 5 \chi^{2}\right.$ test; $\left.p<0.001\right)$.

\section{Biological parameters}

All the haematological measurements were in the normal range both in control and $\mathrm{Mn}$ exposed workers. The erythropoietic parameters (red blood cell count, haemoglobin, mean corpuscular volume, mean corpuscular haemoglobin concentration), and serum iron concentration, however, exhibited a consistent and statistically significant trend towards lower values in the Mn exposed workers (results not shown). The results of the other serum measurements (calcium, LH, FSH, prolactin) were not significantly different between the groups (table 7).
Table 5 Prevalence of normal values for eye-hand coordination parameters in control and Mn exposed workers

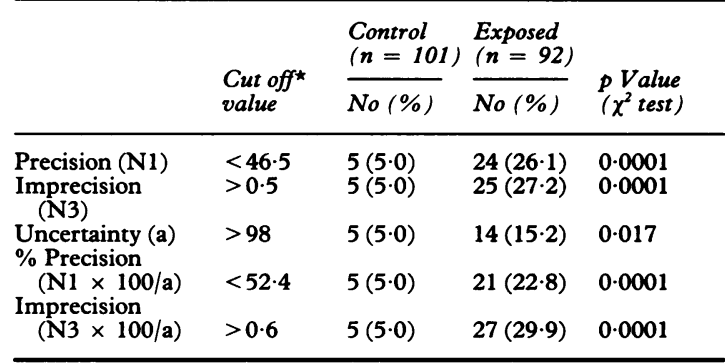

*Fifth percentile values of the control group for precision and \% precision and 95 th percentile values for imprecision, uncertainty and $\%$ imprecision.

DOSE-EFFECT AND DOSE-RESPONSE RELATION

The possible association between the intensity of $\mathrm{Mn}$ exposure (expressed in terms of $\mathrm{MnB}, \mathrm{MnU}$, or lifetime integrated exposure to respirable or total $\mathrm{Mn}$ dust) and the intensity of neurofunctional disturbances or the prevalences of abnormal score values in the neurofunctional tests was examined. Pearson and Spearman correlation coefficients between the scores of the various neurofunctional effect variables (see tables 2, 4, and 6) and the variables of $\mathrm{Mn}$ exposure did not show clear cut dose-effect relations on an individual basis. The dose-response (prevalence of abnormal results) relations were examined for those neurofunctional tests that showed significantly increased prevalences of abnormal values in the $\mathrm{Mn}$ group compared with the control group, that is eyehand coordination, hand steadiness, and reaction time. As the various parameters monitored by each of these tests are not strictly independent, only one parameter per test, which may be considered representative of the psychomotor performance investigated, was selected. Therefore, eye-hand coordination was considered abnormal when the score for the \% precision measurement was lower than 52.4 (see table 5), hand steadiness was considered abnormal when the score for the $3.5 \mathrm{~mm}$ hole exceeded 27 (95th percentile of control group), and

Table 6 Hand steadiness scores in control and Mn exposed workers

\begin{tabular}{|c|c|c|c|c|c|c|c|}
\hline & \multicolumn{3}{|c|}{ Control $(n=101)$} & \multicolumn{3}{|c|}{ Exposed $(n=91)^{\star}$} & \multirow{2}{*}{$\begin{array}{l}\text { p Value } \\
\text { (Mann-Whitney U test) }\end{array}$} \\
\hline & Mean & $S D$ & Range & Mean & $S D$ & Range & \\
\hline $\begin{array}{l}\text { Hole } 5(6 \mathrm{~mm}) \\
\text { Hole } 6(5 \mathrm{~mm}) \\
\text { Hole } 7(4.5 \mathrm{~mm}) \\
\text { Hole } 8(4 \mathrm{~mm}) \\
\text { Hole } 9(3.5 \mathrm{~mm})\end{array}$ & $\begin{array}{r}0 \cdot 05 \\
0 \cdot 31 \\
1 \cdot 28 \\
3 \cdot 62 \\
13 \cdot 41\end{array}$ & $\begin{array}{l}0.31 \\
0.76 \\
1 \cdot 76 \\
3.42 \\
9 \cdot 15\end{array}$ & $\begin{array}{l}0-2 \cdot 7 \\
0-5 \cdot 0 \\
0-10 \cdot 7 \\
0-19 \cdot 7 \\
0 \cdot 7-62 \cdot 7\end{array}$ & $\begin{array}{c}0.13 \\
0.58 \\
1.63 \\
4.40 \\
16 \cdot 2\end{array}$ & $\begin{array}{l}0 \cdot 29 \\
0 \cdot 80 \\
1 \cdot 68 \\
3 \cdot 24 \\
9 \cdot 15\end{array}$ & $\begin{array}{l}0-1 \cdot 7 \\
0-3 \cdot 7 \\
0-9 \cdot 7 \\
0-13 \\
2 \cdot 3-53 \cdot 3\end{array}$ & $\begin{array}{l}\text { NS }(0.060) \\
0.018 \\
\text { NS } \\
\text { NS } \\
0.032\end{array}$ \\
\hline
\end{tabular}

*One subject deleted because of appreciable resting tremor.

NS $=$ Not statistically significant. 
Table 7 Serum measurements in control and Mn exposed workers

\begin{tabular}{|c|c|c|c|c|c|c|c|}
\hline & \multicolumn{3}{|c|}{ Control $(n=101)$} & \multicolumn{3}{|c|}{ Exposed $(n=92)$} & \multirow{2}{*}{$\begin{array}{l}\text { p Value } \\
\text { (t test) }\end{array}$} \\
\hline & Mean & $S D$ & Range & Mean & $S D$ & Range & \\
\hline $\begin{array}{l}\text { Calcium }(\mathrm{mg} / \mathrm{dl}) \\
\text { Iron }(\mu \mathrm{g} / \mathrm{dl}) \\
\text { LH }\left(10^{-3} \mathrm{IU} / \mathrm{ml}\right)^{\star} \\
\text { FSH }\left(10^{-3} \mathrm{IU} / \mathrm{ml}\right)^{\star} \\
\text { Prolactin }\left(10^{-6} \mathrm{IU} / \mathrm{ml}\right)^{\star}\end{array}$ & $\begin{array}{l}9 \cdot 73 \\
123(115) \dagger \\
6 \cdot 04(5 \cdot 50) \dagger \\
4 \cdot 76(4 \cdot 10) \dagger \\
116 \cdot 1(101 \cdot 7) \dagger\end{array}$ & $\begin{array}{c}0 \cdot 44 \\
45 \\
2 \cdot 56 \\
3 \cdot 67 \\
63 \cdot 4\end{array}$ & $\begin{array}{c}8 \cdot 71-10 \cdot 87 \\
52-299 \\
1 \cdot 48-13 \cdot 95 \\
1 \cdot 35-28 \cdot 77 \\
21 \cdot 7-378 \cdot 7\end{array}$ & $\begin{array}{l}9.66 \\
109(105) \dagger \\
6 \cdot 44(5 \cdot 99) \dagger \\
4.59(4 \cdot 30) \dagger \\
125 \cdot 4(104 \cdot 7) \dagger\end{array}$ & $\begin{array}{c}0 \cdot 47 \\
32 \\
2 \cdot 71 \\
1 \cdot 77 \\
99 \cdot 9\end{array}$ & $\begin{array}{c}8 \cdot 20-10 \cdot 57 \\
59-223 \\
2 \cdot 43-20 \cdot 38 \\
2 \cdot 10-10 \cdot 17 \\
29 \cdot 0-742 \cdot 2\end{array}$ & $\begin{array}{l}\text { NS } \\
0.021(0.052) \\
\text { NS } \\
\text { NS } \\
\text { NS }\end{array}$ \\
\hline
\end{tabular}

*Pituitary hormones are expressed in international units: LH in WHO 1st IRP68-40 units, FSH in WHO 2nd IRP78-549 units, and prolactin in WHO 1st IRP75-504 units.

†Geometric mean.

$\mathrm{NS}=$ Not statistically significant.

visual reaction time was considered abnormal when the subject's simple reaction time measurements were increased for each 2 minute examination period (cut off values, see table 3 ). These three parameters were not age related.

The relations between the prevalences of abnormal values and the intensity of $\mathrm{Mn}$ exposure were first examined on a group basis. The control workers were considered as a separate group and the $\mathrm{Mn}$ exposed workers were classified into three subgroups according to $\mathrm{MnB}(<0.7,0.7-1.0,>1.0 \mu \mathrm{g} \mathrm{Mn} / 100 \mathrm{ml}$ blood), $\mathrm{MnU}$ ( $<0.5,0.5-1 \cdot 2,>1.2 \mu \mathrm{g} \mathrm{Mn} / \mathrm{g}$ creatinine in urine), lifetime integrated exposure to respirable $\mathrm{Mn}$ dust $\left(<600,600-1200,>1200 \mu \mathrm{g} \mathrm{Mn} / \mathrm{m}^{3} \times\right.$ year), and lifetime integrated exposure to total $\mathrm{Mn}$ dust ( $<2500,2500-6000,>6000 \mu \mathrm{g} \mathrm{Mn} / \mathrm{m}^{3} \times$ year). The number of subjects in each subgroup comprises about one third of the $\mathrm{Mn}$ group. The prevalences of

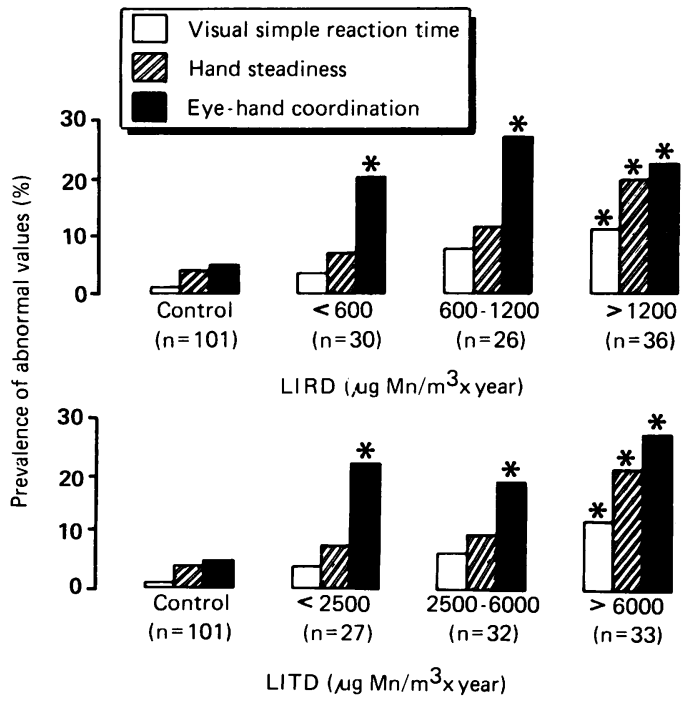

Figure 3 Dose-response relation between lifetime integrated exposure to total (LITD) or respirable (LIRD) Mn dust and the prevalences of abnormal outcome for three

psychomotor performances. Prevalences significantly different from the control group are indicated with an asterisk. abnormal performance for simple reaction time, eyehand coordination, or hand steadiness were not found to be related to the concentrations of $\mathrm{Mn}$ in blood or urine. The prevalences of abnormal test results for the three psychomotor performances, however, increased with increasing concentrations of integrated respirable or total dust (fig 3;2 $2 \times 4 \chi^{2}$, $p<0.05)$. The results do not permit us to suggest an external exposure concentration without adverse effect.

A logistic regression model was used to assess the probability of developing an abnormal psychomotor performance as a function of lifetime integrated exposure to respirable (LIRD) or total (LITD) $\mathrm{Mn}$ dust (log values). Table 8 shows results of this analysis after transformation of the coefficient $\beta_{1}$ into an OR and its $95 \%$ CI. A statistically significant logistic regression was found for hand steadiness ( $3.5 \mathrm{~mm}$ hole) as a function of log LITD $(\mathrm{p}=0.029)$, whereas that as a function of $\log$ LIRD

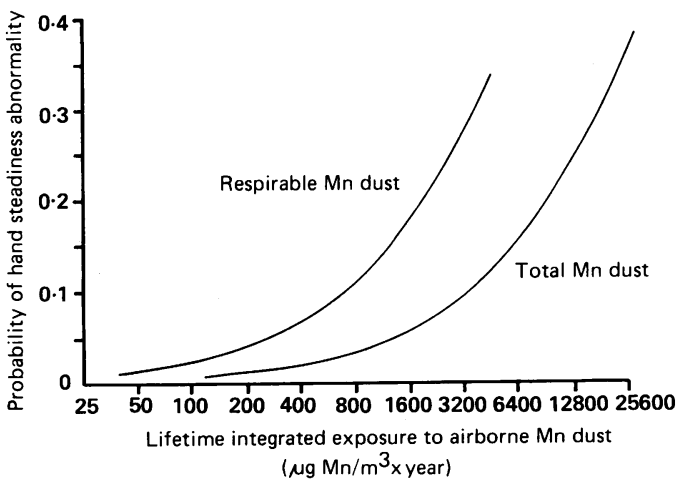

Figure 4 Probability of abnormal hand steadiness as a function of lifetime integrated exposure to respirable (LIRD) or total (LITD) airborne Mn dust. The equations of the logistic regression models are:

$$
\begin{aligned}
& \ln \frac{p}{1-p}=1.8615 \times \log \operatorname{LIRD}\left(\mu \mathrm{gn} / \mathrm{m}^{3} \times \text { year }\right) \\
& \begin{aligned}
\ln \frac{p}{1-p}= & 1.8856 \times \log \operatorname{LITD}\left(\mu g \mathrm{Mn} / \mathrm{m}^{3} \times \text { year }\right) \\
& -8.8728,(p=0.029) .
\end{aligned}
\end{aligned}
$$


Table 8 Odds ratio for abnormal outcome of three psychomotor performances in the Mn group (n=92) calculated from a logistic regression model with either log LIRD or log LITD as independent regression variable

\begin{tabular}{|c|c|c|c|}
\hline$M n$ exposure & $\begin{array}{l}\text { Simple reaction time }(4 \times 2 \text { min period }) \\
O R \dagger(95 \% C I) \ddagger\end{array}$ & $\begin{array}{l}\text { Eye-hand coordination (\% precision) } \\
O R(95 \% \mathrm{CI})\end{array}$ & $\begin{array}{l}\text { Hand steadiness ( } 3.5 \mathrm{~mm} \text { hole) } \\
O R(95 \% \mathrm{CI})\end{array}$ \\
\hline $\begin{array}{l}\log \text { LIRD } \\
\log \text { LITD }\end{array}$ & $\begin{array}{l}5.96(0.55-64.7) \\
4.22(0.58-30 \cdot 9)\end{array}$ & $\begin{array}{l}1.34(0.44-4.03) \\
1.63(0.59-4.47)\end{array}$ & $\begin{array}{l}6 \cdot 43^{\star}(0 \cdot 97-42 \cdot 7) \\
6 \cdot 59^{\star \star}(1 \cdot 20-36 \cdot 1)\end{array}$ \\
\hline
\end{tabular}

${ }^{\star} \mathrm{p}=0.054 ;{ }^{\star \star} \mathrm{p}=0.029$ (logistic regression).

+OR, Odds ratio.

$\$ 95 \% \mathrm{CI}, 95 \%$ confidence interval of odds ratio.

$\S L I R D$ and LITD, lifetime integrated exposure to respirable and total $\mathrm{Mn}$ dust respectively $\left(\mu \mathrm{g} \mathrm{Mn} / \mathrm{m}^{3} \times\right.$ year $)$.

nearly reached the level of statistical significance $(p=0.054)$. Figure 4 illustrates these relations. The upper limit of the $95 \%$ CI for LITD or LIRD corresponding to a $5 \%$ probability of abnormal hand steadiness amounts to $3575 \mu \mathrm{g} \mathrm{Mn} / \mathrm{m}^{3} \times$ year for LITD and to $730 \mu \mathrm{g} \mathrm{Mn} / \mathrm{m}^{3} \times$ year for LIRD.

\section{Discussion}

Our previous cross sectional study ${ }^{2}$ on workers from a $\mathrm{Mn}$ oxide and salt producing plant has suggested that exposure to airborne dust (total dust) below the current ACGIH TWA $\left(5 \mathrm{mg} / \mathrm{m}^{3}\right)$ for less than 20 years may still lead to preclinical signs of intoxication particularly respiratory symptoms, slight changes in lung ventilatory parameters, and alteration of various neurofunctional performances (simple reaction time, hand tremor, short term memory) and moderate hypercalcaemia.

The present study on workers exposed to $\mathrm{MnO}_{2}$ in a dry alkaline battery factory supports this conclusion. Their average lifetime integrated exposure to $\mathrm{Mn}$ (total dust) was $\mathbf{5 0 \%}$ less than that of the workers examined during our previous study $\left(3.5 \mathrm{mg} / \mathrm{m}^{3} \times\right.$ year $v 6.7 \mathrm{mg} / \mathrm{m}^{3} \times$ year). Their lifetime integrated exposure to respirable Mn dust ranged from 0.04 to $4.43 \mathrm{mg} / \mathrm{m}^{3} \times$ year (geometric mean $0.79 \mathrm{mg} / \mathrm{m}^{3} \times$ year). Despite the similar current mean concentrations of airborne $\mathrm{Mn}$ (total dust) in both plants (geometric mean 0.94 and $0.95 \mathrm{mg} \mathrm{Mn} / \mathrm{m}^{3}$ in previous and present study respectively), the mean $\mathrm{MnU}$ and $\mathrm{MnB}$ in the workers from the dry alkaline battery exposed exclusively to $\mathrm{MnO}_{2}$, were lower than those measured in the workers examined previously who were exposed not only to $\mathrm{Mn}$ oxides ( $\mathrm{MnO}, \mathrm{MnO}_{2}, \mathrm{Mn}_{3} \mathrm{O}_{4}$ ) but also to several manganese salts $\left(\mathrm{MnSO}_{4}, \mathrm{MnCO}_{3}\right.$, $\mathrm{Mn}\left(\mathrm{NO}_{3}\right)_{2}, \mathrm{Mn}$ acetate). The different internal dose of $\mathrm{Mn}$ in the workers from the two factories may be partly due to differences in the bioavailability of $\mathrm{Mn}$ oxide and various $\mathrm{Mn}$ salts.

In agreement with their lower internal and lifetime integrated exposure to manganese, the dry alkaline battery workers exhibited less adverse effects than those of the salt and oxide producing plant. For example, there were no indications of lung impairment, biological disturbance of calcium metabolism and the hypothalamo pituitary testicular axis, or increased prevalence of neurovegetative complaints. Unlike the previous Mn study, no significant short term memory deficit was detected in the present study; however, the other neurofunctional performances studied (simple reaction time, eye-hand coordination, and hand steadiness) were still altered by $\mathrm{Mn}$ exposure. This indicates that the central nervous system represents the critical organ after long term exposure to $\mathrm{Mn}$.

As in our previous study, the examination of the dose-response relation does not show any clear cut association between the neurofunctional disturbances and the internal exposure parameters $(\mathrm{MnB}$, $\mathrm{MnU})$. There is, however, some tendency for the prevalence of these alterations (visual reaction time, hand steadiness, eye-hand coordination) to be associated with the integrated exposure to airborne Mn (total and respirable dust). Analysis of the data on a group basis (fig 3 ) does not permit us to identify a threshold effect level for airborne $\mathrm{Mn}$. It can, however, be concluded that a lifetime integrated exposure to $\mathrm{MnO}_{2}$ dust above $6000 \mu \mathrm{g} \mathrm{Mn} / \mathrm{m}^{3}$ × year (total dust) or above $1200 \mu \mathrm{g} \mathrm{Mn} / \mathrm{m}^{3} \times$ year (respirable dust) causes slight neurofunctional changes in a significant proportion of exposed subjects. Logistic regression analysis of the data suggests that tremor (hand steadiness) is the most appropriate parameter to define a threshold effect level (table 8, fig 4). It indicates that a lifetime integrated exposure to $\mathrm{Mn}$ dust (as $\mathrm{MnO}_{2}$ ) above $3575 \mu \mathrm{g} \mathrm{Mn} / \mathrm{m}^{3} \times$ year (total dust) or $730 \mu \mathrm{g} \mathrm{Mn} / \mathrm{m}^{3} \times$ year (respirable dust) may lead to an increased risk of tremor. Of course, this conclusion implies that oral exposure of the workers to Mn dust is not important or because of the high capacity of the liver to remove $\mathrm{Mn},{ }^{14}$ the amount of Mn transferred from the gut to the systemic circulation is not greatly influenced by an additional oral intake from occupational exposure.

This study also underlines the need to implement an appropriate surveillance programme to detect the most susceptible subjects as early as possible. The latter should include the regular application (for example, every 12 months) of a standardised questionnaire on lung and central nervous system symptoms, the performance of a spirometric test, and the monitoring of simple reaction time and hand tremor with well validated methods (for example, orthokin- 
esimeter and hole tremormeter). Despite the fact that $\mathrm{MnU}$ has limited usefulness on an individual basis to assess exposure, its inclusion in a surveillance programme may also be considered. Because on a group basis, MnU seems partly influenced by recent exposure, its regular determinaton in a group of workers may detect changes in environmental pollution and a time trend in the risk of overexposure. Studies are now needed to assess whether the preclinical neurological signs of excessive exposure to $\mathrm{Mn}$ are reversible when exposure is decreased or has ceased and whether moderate exposure to $\mathrm{Mn}$ may also favour the occurrence of degenerative changes in the central nervous system in advanced age. Such information is relevant to better define the acceptable exposure level to $\mathrm{Mn}$.

We are grateful to Messrs J Casters, R Ceulemans, $\mathrm{J} M$ Defeld, T Seminck, Mrs M J Cremers, and Miss C Gathy for their skilful technical assistance. This investigation was supported by the European Community of Coal and Steel.

Requests for reprints to: $\mathbf{R} \mathbf{R}$ Lauwerys, Unité de Toxicologie Industrielle et Médecine du Travail, Catholic University of Louvain, 30.54 Clos Chapelle-aux-Champs, B-1200 Brussels, Belgium.

1 World Health Organisation. Environmental health criteria 17: Manganese. Geneva WHO, 1981:1-110.

2 Roels H, Lauwerys R, Buchet JP, Genet P, Sarhan MJ, Hanotiau
I, et al. Epidemiological survey among workers exposed to manganese: effects on lung, central nervous system, and some biological indices. Am J Ind Med 1987;11:307-27.

3 Lauwerys R, Roels H, Genet P, Toussaint G, Bouckaert A, De Cooman S. Fertility of male workers exposed to mercury vapour or to manganese dust: a questionnaire study. Am J Ind Med 1985;7:171-6.

4 Roels H, Lauwerys R, Genet P, Sarhan MJ, de Fays M, Hanotiau I, Buchet JP. Relationship between external and internal parameters of exposure to manganese in workers from a manganese oxide and salt producing plant. Am J Ind Med 1987;11:297-305.

5 Crapo RO, Morris AH, Gardner RM. Reference spirometric values using techniques and equipment that meet American Thoracic Society recommendations. Am Rev Respir Dis 1981;123:659-64.

6 Roels HA, Lauwerys RR, Buchet JP, Bernard A, Barthels A, Oversteyns M, Gaussin J. Comparison of renal function and psychomotor performance in workers exposed to elemental mercury. Int Arch Occup Environ Health 1982;50:77-93.

7 Roels H, Gennart JP, Lauwerys R, Buchet JP, Malchaire J, Bernard A. Surveillance of workers exposed to mercury vapour: validation of a previously proposed biological threshold limit value for mercury concentration in urine. Am J Ind Med 1985;7:45-71.

8 Buchet JP, Lauwerys R, Roels H. Determination of manganese in blood and in urine by flameless atomic absorption spectrophotometry. Clin Chim Acta 1976;73:481-6.

9 Roels HA, Buchet JP, Lauwerys R, Bruaux P, Claeys-Thoreau $\mathrm{F}$, Lafontaine $\mathrm{A}$, et al. Lead and cadmium absorption among children near a nonferrous metal plant. Environ Res 1978;15:290-308.

10 Magos L, Clarkson TW. Atomic absorption determintion of total, inorganic, and organic mercury in blood. $J$ Assoc Off Anal Chem 1972;55:966-71.

11 Henry RJ. Clinical chemistry: principles and technics. 3rd ed. New York: Harper and Row, 1965.

12 SAS Institute. SAS/STAT guide for personal computers. Version 6. Cary, NC: SAS Institute Inc, 1987.

13 Schlesselman JJ. Case-control studies: design, conduct, analysis. New York: Oxford University Press, 1982:225-63.

14 Gibbons RA, Dixon SN, Hallis K, Russel AM, Sansom BF, Symonds HW. Manganese metabolism in cows and goats. Biochim Biophys Acta 1976;444:1-10.

Accepted 3 June 1991 